\title{
Extent of Community Participation in the Provision of School Plant in the Administration of Public Secondary Schools in Enugu State
}

\author{
Gertrude N. Okenwa \\ Department of Educational Foundations, \\ Enugu State University of Science and Technology, Enugu, Nigeria. \\ Rosemary 0. Igbo \\ Department of Continuing Education \& Community Development \\ Ibrahim Badamasi Babangida University, Lapai, Nigeria
}

Doi:10.5901/jesr.2013.v3n4p53

\begin{abstract}
The study examined the extent of community participation in the provision of school plant in the administration of public secondary schools in Enugu State. One research question and one null hypothesis guided the study. Descriptive survey research design employing simple random sampling was used to sample 7211 of all the principals and classroom teachers from both rural and urban schools in Enugu State: Out of which 702 respondents responded to the study. The instrument used for data collection was questionnaire. The questionnaire was face validated by experts in the field of education, a reliability co-efficient of 0.73 was obtained using croanbach alpha method of determining internal consistency of the instrument. The research question was answered using mean and grand mean while the hypothesis was tested using t-test statistics. The result revealed that the extent of community participation in the provision of school plant in public secondary schools in Enugu State was low. Significant differences did not exist in the mean perception scores of principals and teachers regarding the extent of community participation in provision of school plant in the public secondary schools in Enugu State. It was recommended among other things that regular interactive programmes for instance radio-link and meet the people-tour should be conducted for both the principals and community representatives, the need for provision of school plant in schools.
\end{abstract}

Key words: Extent, community participation, administration, school plant, public secondary school.

\section{Introduction}

Extent in this study means low far the members of the community have been contributing in the affairs of public secondary school administration as regards to provision of school plant for effective teaching and learning. In this study also, community participation in school administration is the involvement of the community to achieve educational goals and objectives. Education at secondary school level is defined by Federal Republic of Nigeria (2004), as the form of education children receive after primary education and before the tertiary stage. The broad aims of secondary education as stated in the Federal Republic of Nigeria (2004) include preparation for useful living within the society and preparation for higher education. In the policy document, it is stated that government welcomes the participation of voluntary agencies and communities in the 
establishment and management of secondary schools. This is because the provision of education has become very expansive not to be left for the government alone. The school and community are two inspirable entities which are mutually dependent on one another. In Nigeria and indeed in many other African countries, the typical image of a community is that of a medium sized rural village with a close-knit group of inhabitants, largely, self contained with every body knowing and standing in accepted relationship with one another Amujiri, (2000).

Ngoka (2003), observed that a community is a body of people living in the same locality and having a common cultural and historical heritage and the willingness to work together. He identified some of the agencies within the communities through which effective and efficient school-community relationships are maintained. They include Parents Teachers Association (PTA) School Based Management Committee (SBMC), Social Clubs, Old Student's Association, Board of Governors and Women Association. In the same vein, Nwangwu, (2007), observed that a school does not exist in isolation. It exists in social setting, in other words, it is an integral part of the community in which it is situated. This therefore means that the community as well as the general public in one way or the other owns and supports the school. He further stated that as a result of this support, these people deserve to be informed on regular basis on the progress and activities of the school. Both the school and the community have tremendous influence on the character and behaviour of the youths. The school as well as the community should understand and appreciate the need for mutual co-existence. There is, therefore, absolute need to create opportunities and forum where views on school policies, programmes, activities are discussed.

Administration is generally defined as the process of working with and through others to efficiently accomplish organizational goals (Aguba, 2009). In the words of Veig in Olewe (2007), sees administration as a determined action taken in pursuit of conscious purpose. It is the systematic ordering of affairs and the calculated use of resources, aimed at making those things happen which we want to happen simultaneously preventing developments that fail to square with our intentions. It is the marshaling of available labour and materials in order to gain that which is desired at the harvest cost of energy, time and money.

Public secondary schools as used in this study refer to all the secondary schools that are owned, financed and managed by the Enugu State government. The school is the agent of socialization after the home. Therefore, the school exists for the community and the community exists and acts as clients to the school. This is because without the community, there would not be the school.

Okwor (2008), emphasized the need for cooperation between the school and the community in the education of children because the school and the community are symbiotically related. Advocating move on the importance of home-school cooperation, Akubue - 1992 in Igbo (2002) stated that whilst few would doubt that the main influence of child's life is his home that of the school is a good second home. The closer the cooperation between these two the happier the child and more successful his development in every respect. Therefore, school community relations is a series of planned activities and media through which the school seek to learn about the community. These activities include informing the community about and interpreting when necessary, the purpose, programmes, problems and needs of the schools.

The school plant in this study is defined to include the site, the buildings, equipment and all facilities of a school (Olaturibosun 2005 in Onyene 2007). To say that such plant of most schools in Enugu State is dilapidated, inadequate and unmaintained condition is stating the obvious. It is basic that adequate provision and maintenance of school plant enhance effective teaching and learning. No level of education can survive in the absence of physical facilities. The Federal Republic of Nigeria (2004) realized the value of physical facilities in schools when it stated that "government will ensure that schools are properly equipped to promote sound and effective teaching, and in particular that suitable textbooks and libraries are provided for schools". However, the extent to which government has succeeded in schools where enough facilities are lacking. Okpala (2005) commented that it is disheartening that in our school today, you find nothing but 
dull uninviting sagging roof and colourless dilapidating walls. As he said, it is under this appalling physical condition that students and teachers are squatting in the name of education. He suggested that school buildings should be well built and attractive as well as equipped. He also concluded that lack of facilities is a serious contributory factor hindering teachers with initiatives and zeal from making use of audio-visual aids and this has made teachers to develop a non-challant attitude towards their work.

In a similar view, Okoro (2008), stated that most of the physical facilities in schools are grossly inadequate as a result of the population explosion in primary and secondary schools. Okoro stated further that very often two classes are placed in one room and the classroom space is in most cases inadequate and that seats and tables are in short supply and the children are uncomfortable. He said that as a result of this, quality education is sacrificed and standard fails. He therefore opined that the PTA and school board of governors should help to generate funds for physical facilities especially at this point in time when economic depression has adversely affected the finances both the federal and state government.

Air waves and print media are on daily basis inundated with reports on high incidence of mass failure of secondary school students in various examinations conducted by the West African Examinations Council (WAEC), National Examination Council (NECO) and the Joint Admissions and Matriculation Board (JAMB). Personal experience has shown that the ugly situation is necessitated by poor provision of school plant in most secondary schools and constant reports of vandalization and theft of the existing facilities in the schools in Enugu State.

All these point to the fact that government can no longer bear the burden alone. The community is expected to participate actively in the administration of secondary schools but what remains uncertain is the extent of its involvement. This forms the problem of the study, which focuses on the extent of community participation in the provision of school plant in the administration of public secondary schools in Enugu State.

\section{Purpose of the Study}

The purpose of the study was to assess the extent of community participation in the provision of school plant in the administration of public secondary schools in Enugu State. Specifically, the study sought to:

Investigate the extent of community participation in the provision of school plant.

\section{Research Question}

To what extent does the community participate in the provision of school plant?

\section{Hypothesis}

The course of this study, a hypothesis was tested at .05 level of significance and an appropriate degree of freedom.

There is no significance difference in the mean perception scores of principals and teachers on the extent of community participation in the provision of school plant.

\section{Method}

The design of the study was descriptive survey research design because it concentrated on discussing events as they were without any interference on what was observed. The population for study was 7211 of all the principals and classroom teachers from both rural and urban schools in Enugu State. 
The instrument for data collection was a 6-itemed four point scale response option questionnaire, with a response format of very great extent (VGE), great extent (GE) low extent (LE), very low extent (VLE) and a numerical value of 4, 3, 2 and 1 respectively. The instrument was validated by three experts in the field of Education. Based on their comments, some items were reconstructed. The reliability of the instrument was determined using croanbach's alpha formula and internal consistency reliability co-efficient of 0.73 was obtained. The questionnaire was administered to the principals and classroom teachers during their monthly meetings in their various schools with the help of trained research assistants.

The research question was analyzed using mean and grand mean, while the hypothesis was tested at .05 level of significance using t-test statistics. The decision rule was as follows. Any item with mean 2.50 and above was accepted which shows that the community participated in the provision of school plant in the administration of public secondary schools to a great extent; while those below 2.50 were not accepted, which indicates that community participated in the provision of school plant to a low extent. Where the calculated t-value was equal or greater than the critical value of 4 , the null hypothesis was rejected but if less than the critical t-value, it was not rejected.

\section{Results}

The results of the data analysis were presented in tables according to the research question and hypothesis.

\section{Research Question}

To what extent does the community participate in the provision of school plant?

Table 1: Mean scores of respondents one extent of community participation in provision of school plant.

\begin{tabular}{|c|c|c|c|c|}
\hline $\mathbf{S} / \mathbf{N}$ & ITEMS & $\overline{\mathbf{x}}$ & SD & Decision \\
\hline 1 & $\begin{array}{l}\text { Principals allowance community to repair facilities that } \\
\text { are available in the school }\end{array}$ & 2.80 & 1.00 & GE \\
\hline 2 & The community provides the erection of needed facilities & 1.82 & 0.90 & LE \\
\hline 3 & $\begin{array}{l}\text { The school maintains existing school plant, facilities with } \\
\text { the help of the community. }\end{array}$ & 1.78 & 0.89 & LE \\
\hline 4 & $\begin{array}{l}\text { The community provide facilities live furniture to the } \\
\text { school }\end{array}$ & 1.73 & 0.81 & LE \\
\hline 5 & The community donate lands freely for school use. & 1.71 & 0.82 & LE \\
\hline \multirow[t]{2}{*}{6} & $\begin{array}{l}\text { The community participate in the security of the school } \\
\text { properties. }\end{array}$ & 1.99 & 0.92 & LE \\
\hline & Grand Mean & 1.97 & 0.98 & LE \\
\hline
\end{tabular}

\section{Key GE = Great Extent}

The table shows that a grand mean of 1.97 was obtained. This is an indication that community participation in the provision of school plant in their administration of public secondary schools in Enugu State was to a low extent.

\section{Testing of Null Hypothesis}

There is no significant difference in the mean perception scores of principals and teachers on the extent of community participation in the provision of school plant. 
Table 2: t-test analysis of significant difference between the mean scores of principals and teachers on the extent of community participation in the provision of school plant.

\begin{tabular}{|l|l|l|l|l|l|l|l|}
\hline \multicolumn{1}{|c|}{ Respondents } & \multicolumn{1}{|c|}{$\mathbf{n}$} & $\overline{\mathbf{X}}$ & \multicolumn{1}{|c|}{ SD } & \multicolumn{1}{|c|}{ df } & t-cal & t-critical & Decision \\
\hline Principals & 30 & 1.86 & 0.89 & 700 & 1.29 & 1.96 & $\begin{array}{l}\text { Do not } \\
\text { Reject } \\
\mathrm{H}_{0}\end{array}$ \\
\hline Teachers & 672 & 2.08 & 1.02 & 700 & & & \\
\hline
\end{tabular}

The table shows that t-value is 1.29 and the critical value of t was 1.96 since the calculated value of $t$ was less than the critical value of $t$, the null hypothesis was not rejected. This means that no significant difference exist between the mean perception scores of principals and teachers regarding the extent of community participation in the provision of school plant.

\section{Discussion of Findings}

The finding from the research question revealed that extent of community participation in the provision of school plant in public secondary schools in Enugu State was low. This is in the with Okpala (2005) who reported that it is disheartening that in our schools today, one finds nothing but dull university sagging roofs and colourless dilapidating walls. He further stated that it is under the appalling physical conditions that our children and their teachers are squatting in the name of education for teaching and learning. In the same vein, Okoro (2008) was of the opinion that most of the physical facilities in school today are grossly inadequate as a result of population explosion in our secondary schools. And that very often two classes are placed in one room and the classroom space in most cases are inadequate and that seats and tables are in short supply and the children are uncomfortable.

The result from the null hypothesis tested at .05 level of significance showed that there was no significant difference between the mean perception scores of principals and teachers regarding the extent of community participation in provision of school plant in public secondary schools in Enugu State. This was in agreement with the earlier findings of Bosah (1990) that most of the public secondary schools were inadequate provided for, play grounds were ill-equipped, poor library facilities, poor provision of utilities, classrooms and administrative facilities were in poor conditions. This may be as a result of low participation of members of the community in the provision of school plants in public secondary schools.

\section{Conclusion}

The findings showed that, due to non participation of community members in the provision of school plant, most of the buildings in public secondary schools are dilapidated and sagging.

\section{Recommendations}

Based on the findings of the study, the following recommendations were made:

1. The government including the State Ministry of Education and Post Primary School Management Board (PPSMB) should as a matter of urgency make provisions for constant seminars/workshops and conferences for principals and community members on the need for effective community participation in the administration of schools. This will also enhance teaching and learning and effective school administration and management. 
2. The Enugu State Chapter of All Nigerian Conference of Principals (ANCOPs) should encourage their members to attend seminars/workshops/conferences where they will be exposed to erudite scholars in the education industry.

3. Institutions/Non-Governmental Organizations (NGOs) that run programmes on school management should also ensure that community participation in the administration of schools are cardinal aspect of their training programmes especially as it concerns provision of school plant.

\section{References}

Aguba, C.R. (2009). Education administration and management: Issues and perspectives. Enugu: Tons and Tons PDS.

Basah, I.P. (1990). The provision and condition of physical facilities in primary schools in Awka urban area, Unpublished M.Ed Thesis, University of Nigeria, Nsukka.

Federal Republic of Nigeria (2004). National policy on education, Lagos: NERDC.

Igbo, R.O. (2002). Fundamentals of school management. Enugu: Chelson.

Ngoka, G.N. (2003). Concept and issues in advanced education administration. University of Nigeria, Nsukka.

Nwangwu, I.O. (2007). Basic issues in school management. Computer Edge.

Okenwa, G.N. (2013). Extent of community participation in the administration of public secondary schools in Enugu State. Unpublished doctorial thesis. Department of educational foundations, Enugu State: University of Science and Technology, Enugu.

Okpala, C.E.N. (2005). Issues in Nigerian education. Aba: Span

Okwor, R.E. (2008). Parent-teacher association's financial and material support roles in Enugu State secondary school administration, unpublished Ph.D Thesis, University of Nigeria Nsukka.

Olewe, B.N. (2007). Development administration. Aba: Grace Venture.

Onyene, V. (2007). Impersonal skill to effective personnel administration. The fads and the facts. Lagos: Vitaman educational books. 